\title{
Decline in the geographical range of the southern patas monkey Erythrocebus patas baumstarki in Tanzania
}

\author{
Yvonne A. De Jong, Thomas M. Butynski, Lynne A. Is bell and Claire Lewis
}

\begin{abstract}
The southern patas monkey Erythrocebus patas baumstarki is a subspecies thought to be endemic to central north Tanzania but its distribution and abundance is not well documented. We therefore review what is known about the historical and current distribution of the southern patas. It appears that, at present, the southern patas occurs in three populations, in the Serengeti, Mt Kilimanjaro and Arusha. Since 1995 the gaps among these three populations have become larger, thereby increasing their isolation. The available data suggest that, at present, southern patas occur over c. $20,700 \mathrm{~km}^{2}$ (c. $2.3 \%$ of Tanzania's land surface area). In 1995 this was c. $30,800 \mathrm{~km}^{2}$ (c. $3.5 \%$ of the land surface area). As such, the geographical range of the southern patas has declined by c. 33\% since 1995 . There are unlikely to be $>900$ southern patas today, and there could be $<150$. Our recommendations are to (1) maintain an internet accessed database (PatasBase) into which sightings of the southern patas can be entered, (2) interview members of local communities to assess past and current distribution and abundance of the southern patas, (3) conduct field studies to obtain more detailed information on the distribution, abundance, and conservation status of patas in Tanzania, (4) undertake ecological and behavioural research on selected groups of southern patas, and (5) prepare and implement a conservation action plan for the southern patas.
\end{abstract}

Keywords Biogeography, distribution, Erythrocebus patas baumstarki, primate conservation, southern patas, Tanzania.

\section{Introduction}

The patas monkey Erythrocebus patas is a medium-sized (c. 5-18 kg) semi-terrestrial primate that typically lives

Yvonne A. De Jong (Corresponding author) Eastern Africa Primate Diversity and Conservation Programme, Nocturnal Primate Research Group, Oxford Brookes University, P.O. Box 149, 10400 Nanyuki, Kenya. E-mail yvonne@wildsolutions.nl

Thomas M. Butynski Eastern Africa Primate Diversity and Conservation Program, Conservation International, Nanyuki, Kenya.

LynNe A. IsBell Department of Anthropology, University of California, Davis, USA.

Claire Lewis Grumeti Community and Wildlife Conservation Fund, Arusha, Tanzania.

Received 2 October 2007. Revision requested 2 December 2007.

Accepted 19 May 2008. in multi-female, single-male groups of 15-75 individuals. Patas range across sub-Saharan Africa from western Senegal to central Ethiopia and northern Uganda (Hall, 1965; Chism \& Rowell, 1988), and in Kenya and central north Tanzania (Elliot, 1913; Swynnerton \& Hayman, 1951; Hall, 1965; Kingdon, 1971, 1997; Wolfheim, 1983; Isbell, in press). In much of West Africa populations of patas appear to be stable or even increasing (Isbell \& Chism, 2007; Isbell, in press). Patas naturally occur at low densities throughout their range in East Africa (Hall, 1965). Unlike in West Africa, populations in East Africa seem to have declined in recent decades. In Kenya, where patas have been intensively studied, populations have declined (Isbell \& Chism, 2007; De Jong et al., 2008). However, a population of 300-450 patas on the Laikipia Plateau, central Kenya, has remained fairly stable since 1979 as a result of wildlifefriendly practices on those cattle ranches that have large areas of whistling thorn Acacia drepanolobium woodland. These practices include provisioning of water via dams, troughs and tanks (Isbell \& Chism, 2007). A. drepanolobium grows on 'black cotton' soils of impeded drainage (Ahn \& Geiger, 1987) and provides patas with year-round food (gum and insects) within the swollen thorns (Isbell, 1998; Isbell \& Young, 2007).

The flighty behaviour, large home ranges $\left(23 \mathrm{~km}^{2}\right.$, Chism \& Rowell, 1988; $80 \mathrm{~km}^{2}$, Hall, 1965), speed $\left(55 \mathrm{~km} \mathrm{~h}^{-1}\right.$, Hall, 1965 ), and low density of patas make them particularly difficult to find and observe. Habitat degradation, loss, and fragmentation appear to be major threats to the survival of patas in East Africa (Isbell \& Chism, 2007).

The southern patas E. p. baumstarki (Matschie, 1905; Plate 1) appears to be endemic to central northern Tanzania (Elliot, 1913; Hill, 1966; Kingdon, 1997). No other subspecies of patas is known to occur in Tanzania. The historical and current distributions of the southern patas have not been studied. We review the historical distribution of the southern patas, provide information on its current distribution and abundance, and make recommendations for conservation actions.

\section{Study area}

For the purposes of this article the western Serengeti is taken to be the area covered by the Nyakitono Open Area $\left(92 \mathrm{~km}^{2}\right)$, Grumeti Game Reserve $\left(428 \mathrm{~km}^{2}\right)$, Ikona Wildlife Management Area $\left(255 \mathrm{~km}^{2}\right)$ and Ikorongo Game Reserve 


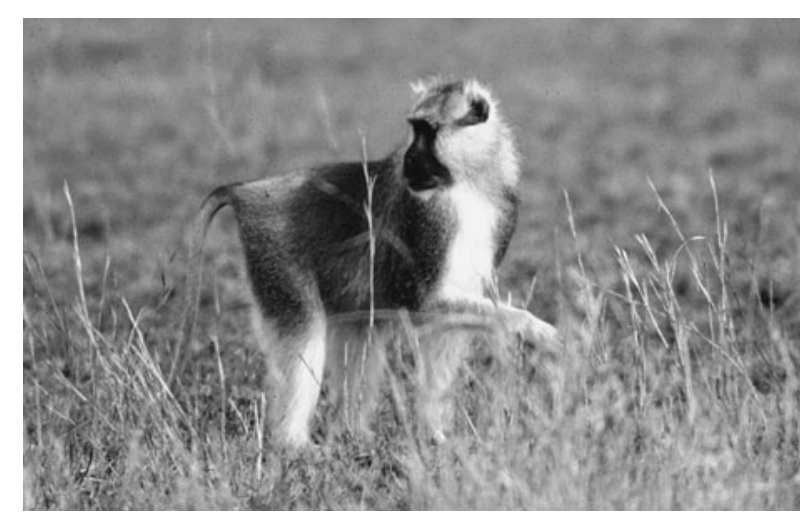

Plate 1 Adult male southern patas monkey E. p. baumstarki in the Northern Extension of the Serengeti National Park, Tanzania. Photograph taken in 1966 by George Schaller.

$\left(567 \mathrm{~km}^{2}\right)$. This area was chosen for survey based on reports by R. Radke (pers. comm.) in 1998 of patas in the western Serengeti. The vegetation in the western Serengeti includes open grassland plains, medium-dense Acacia/Balanites woodland-bushland, and riverine forest along the Grumeti River. Three rivers (Grumeti, Momukomule and Rubana) provide water to the area (Fig. 1). Even during the driest periods these rivers usually provide widely scattered pools of water. The Rubana River, along the western boundary of the Nyakitono Open Area (Fig. 2), is considered the most important wildlife water source in the area. One water trough in this area serves as a permanent water source for wildlife.

\section{Methods}

\section{Data collection}

Data were collected on the historical and current distribution of the southern patas using several approaches: literature surveys, museum reviews, interviews with people in the area, and a reconnaissance survey. Museums were contacted to obtain specimen data, and the primate collections at the US National Museum of Natural History (Washington, DC), American Museum of Natural History (New York), British Museum of Natural History (London), and National $\mathrm{Mu}-$ seums of Kenya (Nairobi) were visited. Rangers, naturalists, researchers, ranch owners/managers, tour operators, camp/ lodge managers, and local people were interviewed about the presence and abundance of the southern patas, and for details of their encounters with patas. More than 120 people were questioned by e-mail or in person. Requests for information on patas in Tanzania were also published in Swara, the magazine of the East African Wildlife Society (De Jong, 2006), and in the Tanzanian Mammal Atlas Project Newsletter (Tanzanian Wildlife Research Institute).

We conducted surveys in the western Serengeti, northwest Tanzania $\left(02^{\circ} \mathrm{O1}^{\prime}\right.$ to $02^{\circ} \mathrm{O} 7^{\prime} \mathrm{S} ; 34^{\circ} 28^{\prime}$ to $34^{\circ} 38^{\prime} \mathrm{E} ; 1,270-$ $1,480 \mathrm{~m}$ altitude; Figs 1 \& 2) during 4-6 October 2005. A total of $12.6 \mathrm{~h}$ were spent searching for patas along a $98 \mathrm{~km}$ transect. The mean rate of travel, acquired from a global positioning system, was $14 \mathrm{~km} \mathrm{~h}^{-1}$. The single encounter with patas was recorded (date, time, coordinates, group size, group composition, and vegetation type) until the group moved out of sight. The survey team consisted of two observers (YDJ \& TMB) and two trained field guides, both of whom had previously observed patas several times in the area.

\section{Distribution mapping}

Data on sightings of patas were categorized as either historical (before 31 December 1995; referred to here as pre-1996) or current (after December 31 1995; referred to here as post-1995). This distinction was made as a first attempt to determine the trend of these patas populations. A zone with a radius of $30 \mathrm{~km}$ was arbitrarily selected and plotted around each locality point to simulate the distribution of patas at each locality. All distribution records were mapped using the software Garmin MapSource v. 6.10.2 (Garmin, Olathe, USA) and MapInfo Professional v. 8.o (Pitney Bowes Mapinfo, Troy, USA).

\section{Results}

Historically, patas have been rarely encountered (or, at least, rarely reported) in Tanzania. Museum specimens are scarce. The British Museum of Natural History holds two specimens from Tanzania: an adult female from Ikoma and an immature female from west Mt Kilimanjaro (Napier, 1981). The Natural History Museum, Berlin, houses six specimens/skulls (five from Ikoma and one from Moshi; R. Asher, pers. comm.). There are no specimens of patas from Tanzania at the United States National Museum, the American Museum of Natural History or the Field $\mathrm{Mu}$ seum of Natural History, Chicago.

We obtained a total of 28 localities in which patas are known to occur, of which 14 are pre-1996 and 14 are post1995. Of the 14 historical records, six (43\%) are in the Serengeti, seven (50\%) are in the vicinity of Mt Kilimanjaro, and one $(7 \%)$ is south-west of Arusha. Of the 14 current records, nine (64\%) are in the Serengeti, one $(7 \%)$ is in the vicinity of Mt Kilimanjaro, and four (29\%) are south-west of Arusha (Fig. 1, Table 1). An additional 12 sources (both historical and current) refer to patas within the Serengeti National Park, and an additional seven sources refer to patas within the Mt Kilimanjaro area (Table 1) but these 19 sources provide insufficient information to plot localities.

It appears that southern patas historically occurred in three populations, all of which were in central north Tanzania. These populations are referred to here as the Serengeti (which includes the western Serengeti), Kilimanjaro and Arusha populations (Fig. 1, Table 1). Together, these three populations historically occupied c. $30,800 \mathrm{~km}^{2}$ 


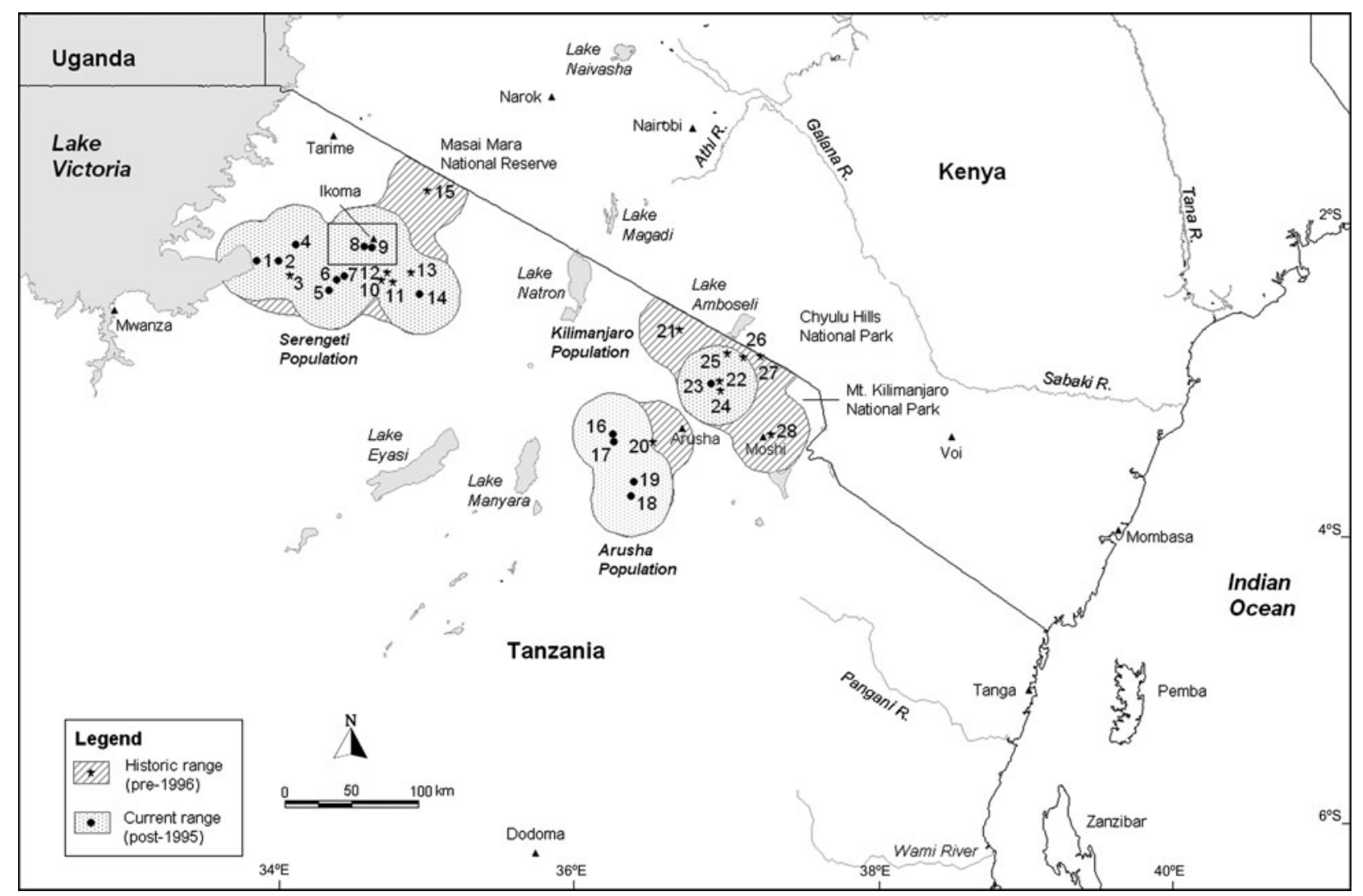

FIG. 1 The known historical (pre-1996) and current (post-1995) distribution of the southern patas monkey E. p. baumstarki in Tanzania. The shaded area around each site has a radius of $30 \mathrm{~km}$. The rectangle indicates the position of the map in Fig. 2. See Table 1 for further details of each numbered site.

within a geographical range encompassed by $01^{\circ} 28^{\prime}-04^{\circ} 02^{\prime} \mathrm{S}$ and $33^{\circ} 36^{\prime}-37^{\circ} 37^{\prime} \mathrm{E}(800-1,580 \mathrm{~m})$, where mean annual rainfall is $25-105 \mathrm{~cm}$ (Table 2). The current geographical range is estimated to be c. $20,700 \mathrm{~km}^{2}$, encompassed by $01^{\circ} 28^{\prime}-04^{\circ} \mathrm{O} 2^{\prime} \mathrm{S}$ and $33^{\circ} 36^{\prime}-37^{\circ} 25^{\prime} \mathrm{E}(950-1,580 \mathrm{~m})$. Table 2 presents more details of the three populations.

\section{Serengeti population}

In the Serengeti researchers rarely encountered patas. G. Frame (pers. comm.) never encountered patas during 9 years of fieldwork there (1965-1966, 1972-1978 and 1993). H. and U. Klingel (pers. comm.) spent 3 years (1996-1965) conducting field work in the Serengeti and Ngorongoro Crater and never encountered patas. G. Schaller (pers. comm.) saw patas only rarely during his 3.3 years (1966-1969) of research in the Serengeti. D. Kreulen (pers. comm.) saw patas in $A$. drepanolobium woodland while working in the Serengeti during 1970-1975. He only encountered patas occasionally in the woodland areas in the west and north of the Serengeti during those years.

In contrast, employees of the Grumeti Community, the Wildlife Conservation Fund, and the Tourism Guides of Singita Grumeti Reserves provided 48 records (total of 261 patas seen) for the Nyakitono Open Area, western Seren- geti, from 1 January 2005 to 31 July 2007 (Fig. 2). All patas records in the Nyakitono Open Area are within an area of c. $150 \mathrm{~km}^{2}$. The habitat used by patas here is woodland dominated by A. drepanolobium and Acacia seyal. The distances from the patas encounter sites to the permanent water source at the Rubana River were $0-13.5 \mathrm{~km}$. Although the staff and guides spend time in the Grumeti Game Reserve, Ikorongo Game Reserve and the Ikona Wildlife Management Area, they have not encountered patas in these areas or south of the Grumeti River.

During our survey in the western Serengeti we encountered only one group of patas, in the Nyakitono Open Area at 17.50 on 4 October 2005. The group comprised one adult male and one adult female with a clinging young. This group was $5.0 \mathrm{~km}$ and $10.7 \mathrm{~km}$ from the two nearest permanent water sources, and $1.2 \mathrm{~km}$ north of the Grumeti River.

\section{Kilimanjaro population}

Hill (1966) and Williams (1987) do not mention patas in the Kilimanjaro area but Swynnerton \& Hayman (1951), Swynnerton (1958), Kingdon (1971), Lernould (1988) and Grimshaw et al. (1995) do. There is only one recent sighting of patas in this area, at Tingatinga in 2001 (P. Jones, pers. comm.; Fig. 1, Table 1). 


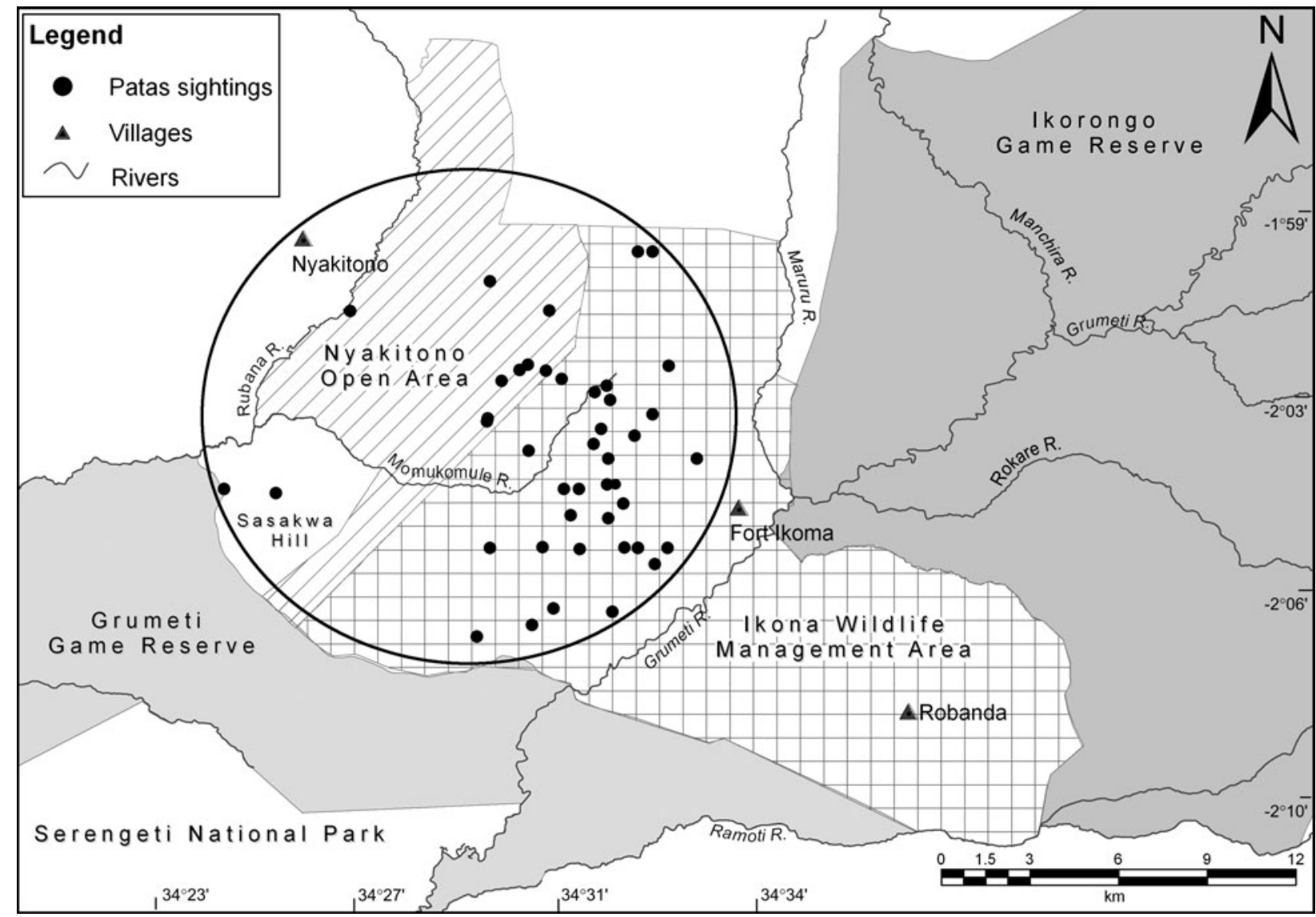

FIG. 2 The current distribution of the southern patas monkey E. p. baumstarki in the Nyakitono Open Area (Site 8 in Table 1 and Fig. 1), western Serengeti, Tanzania.

\section{Arusha population}

Swynnerton \& Hayman (1951), Hill (1966), Kingdon (1971) and Lernould (1988) mention patas in the vicinity of Arusha, whereas Swynnerton (1958), Williams (1987) and Grimshaw et al. (1995) do not. Current sightings indicate that this population persists. Patas were seen at least four times between 1987 and 2000 at Mt Burko (Fig. 1, Table 1) in groups of $>_{14}$ individuals (D. Peterson, pers. comm.). D. Erickson and A. Ambrose (pers. comms) encountered patas at Mt Burko '. . very regularly ... for many years. There is only one group of about $20-30$ individuals.' The last encounter in this area by D. Erickson and A. Ambrose (pers. comms) was in 2007. Patas were also seen two or three times within the last 10 years in the vicinity of $\mathrm{Mt}$ Lolkisale (Fig. 1, Table 1; D. Peterson, pers. comm.). All encounters with patas in this area were in A. drepanolobium dominated woodland on 'black cotton' soils.

\section{Discussion}

Available records indicate that patas have, in historical times, always occurred at low densities in Tanzania, as they do in Kenya (Isbell \& Chism, 2007; De Jong et al., 2008). Historically, it appears that the southern patas occurred in three populations in a total area of c. $30,800 \mathrm{~km}^{2}$ (Table 2), i.e. c. $3.5 \%$ of Tanzania's land surface area. These three populations still exist but the size of their combined geographical ranges has declined to c. $20,700 \mathrm{~km}^{2}$, or c. $67 \%$ of the historical range (c. $2.3 \%$ of Tanzania's land surface area). Based on a 1905 record, Tappen (1960) indicated that the southern limit of patas in Tanzania was Ikoma $\left(2^{\circ} \mathrm{S}\right.$, $\left.35^{\circ} \mathrm{E}\right)$. Hall (1965) reported the southern limit to be at $\mathrm{c}$. $3^{\circ} \mathrm{S}$. This review places the southern limit at $4^{\circ} \mathrm{S}$ (Fig. 1), $180-210 \mathrm{~km}$ further south than indicated by Tappen (1960).

The Serengeti population of patas has always been considered to be isolated (Swynnerton \& Hayman, 1951; Swynnerton, 1958; Hill, 1966; Kingdon, 1971; Williams, 1987; Lernould, 1988; Grimshaw et al., 1995). Kingdon (1971) and Williams (1987) indicated that this population (and, therefore, the subspecies E. p. baumstarki) extends as far north as the Masai Mara, south-west Kenya (Fig. 1). However, during this study, and during a similar study in Kenya (De Jong, 2004; De Jong et al., 2008), no evidence, past or present, was found for patas in the Masai Mara. Hill (1966) noted that the Serengeti population probably did not extend over the Serengeti Plateau, where there is an extensive area of treeless short grassland (White, 1983) that is apparently unsuitable habitat for patas. However, in 1998, an adult male was filmed at the Sametu Kopjes (Fig. 1, Table 1; 
TABLE 1 Historical (pre-1996) and current (post-1995) records for the southern patas monkey E. p. baumstarki in Tanzania. Site numbers correspond to the site numbers in Fig. 1.

\begin{tabular}{|c|c|c|c|c|}
\hline Site number & Locality & Most recent year seen ${ }^{*}$ & Altitude $(\mathrm{m})$ & Source \\
\hline \multicolumn{5}{|c|}{ Serengeti Population } \\
\hline 1 & Ndabaka Gate & C, 1996 & 950 & $\begin{array}{l}\text { H. Marshall \& P. Mbari via } \\
\text { A. Kilpin (pers. comm.) }\end{array}$ \\
\hline 2 & W Handajega & C, 2004 & 1,170 & A. Sirolli (pers. comm.) \\
\hline 3 & Handajega & H, pre-1951 & 1,265 & Swynnerton \& Hayman (1951) \\
\hline 4 & Kirawira & C, 2007 & 1,175 & M. Hutt, R. Knocker (pers. comms) \\
\hline 5 & Nyamuma plain & C, 2003 & 1,340 & A. Sirolli (pers. comm.) \\
\hline 6 & Mbalageti Serengeti Lodge & C, 2004 & 1,400 & A. Sirolli (pers. comm.) \\
\hline 7 & Musabi plain & C, 2004 & 1,320 & A. Sirolli (pers. comm.) \\
\hline 8 & Nyakitono Open Area & C, 2007 & 1,366 & $\begin{array}{l}\text { Y. De Jong, C. Lewis \& } \\
\text { T. Butynski (pers. obs.) }\end{array}$ \\
\hline 9 & Ikoma & C, 2006 & 1,360 & $\begin{array}{l}\text { Matschie (1905); Swynnerton (1945); } \\
\text { Tappen (1960); Natural History Museum, } \\
\text { London, specimens (2021 \& 19371184); } \\
\text { Natural History Museum, Berlin } \\
\text { (13717, 35730, 44730, 72132, 72135, } \\
\text { 721375); A. Kaschula (pers. comm.) }\end{array}$ \\
\hline 10 & Kamariche Hill & $\mathrm{H}, 1970$ & 1,370 & D. Kreulen (pers. comm.) \\
\hline 11 & Serena Hotel vicinity I & H, 1979 & 1,400 & D. Estes (pers. comm.) \\
\hline 12 & Serena Hotel vicinity II & H, 1992 & c. 1,370 & D. Peterson (pers. comm.) \\
\hline 13 & Banagi & H, pre-1951 & 1,460 & Swynnerton \& Hayman (1951) \\
\hline 14 & Sametu Kopjes & C, 1998 & 1,580 & R. Radke (pers. comm.) \\
\hline \multirow[t]{2}{*}{15} & Northern Extension & H, 1966 & 1,565 & G. Schaller (pers. comm.) \\
\hline & $\begin{array}{l}\text { Serengeti National Park } \\
\text { (unspecified) }\end{array}$ & H, pre-1951; C, 2006 & $950-1,830$ & $\begin{array}{l}\text { Swynnerton \& Hayman (1951); } \\
\text { Swynnerton (1958); Hall (1965); Hill (1966); } \\
\text { Kingdon (1971); Williams (1987); } \\
\text { Lernould (1988); Groves (2001); G. Schaller } \\
\text { (pers. comm.); P. Jones (pers. comm.) } \\
\text { K. Howell (pers. comm.); N. Stronach } \\
\text { via W. Newmark (pers. comm.) }\end{array}$ \\
\hline \multicolumn{5}{|c|}{ Arusha Population } \\
\hline 16 & Mt Burko & C, 2007 & c. 1,300 & $\begin{array}{l}\text { D. Peterson, D. Erickson \& G. Ambrose } \\
\text { (pers. comms) }\end{array}$ \\
\hline 17 & Nanja & C, 2006 & 1,390 & $\begin{array}{l}\text { J. Croft, A. Harries \& G. Harries } \\
\text { (pers comms) }\end{array}$ \\
\hline 18 & Mt Lolkisale & C, 2005 & c. 1,450 & C. Foley (pers. comm.) \\
\hline 19 & N Mt Lolkisale & C, post-1997 & c. 1,360 & D. Peterson (pers. comm.) \\
\hline 20 & Kisongo & H, pre-1951 & 1,325 & Swynnerton \& Hayman (1951) \\
\hline \multicolumn{5}{|c|}{ Kilimanjaro Population } \\
\hline 21 & Namanga & H, 1982 & 1,320 & T. Young (pers. comm.) \\
\hline 22 & Simba Farm & H, 1990 & 1,320 & $\begin{array}{l}\text { Grimshaw et al. (1995); C. Foley } \\
\text { (pers. comm.) }\end{array}$ \\
\hline 23 & Tingatinga & C, 2001 & 1,320 & P. Jones (pers. comm.) \\
\hline 24 & Engare Nairobi & H, pre-1951 & 1,320 & Swynnerton \& Hayman (1951) \\
\hline 25 & Lerangwa & H, 1990 & 1,150 & C. Foley (pers. comm.) \\
\hline 26 & NW Mt Kilimanjaro & H, 1995 & 1,385 & W. Newmark (pers. comm.) \\
\hline 27 & $\begin{array}{l}\text { N Mt Kilimanjaro } \\
\text { Migration Corridor }\end{array}$ & H, 1990 & 1,450 & $\begin{array}{l}\text { Grimshaw et al. (1995); P. Jones } \\
\text { (pers. comm.) }\end{array}$ \\
\hline \multirow[t]{2}{*}{28} & Moshi & H, 1932 & 800 & $\begin{array}{l}\text { Natural History Museum, Berlin, } \\
\text { specimen }\end{array}$ \\
\hline & $\begin{array}{l}\text { Mt Kilimanjaro Area } \\
\text { (unspecified) }\end{array}$ & H, pre-1951; C, 2006 & $>1,150$ & $\begin{array}{l}\text { Swynnerton (1958); Kingdon (1971); } \\
\text { Napier (1981); Lernould (1988); } \\
\text { Grimshaw et al. (1995); Natural } \\
\text { History Museum, London, specimen; } \\
\text { C. Foley (pers. comm.) }\end{array}$ \\
\hline
\end{tabular}

${ }^{\star} \mathrm{H}$, historical; C, current 
TABLE 2 Distribution, habitat and abundance of the southern patas monkey E. p. baumstarki in Tanzania.

\begin{tabular}{|c|c|c|c|c|}
\hline & \multicolumn{4}{|l|}{ Population } \\
\hline & Serengeti & Kilimanjaro & Arusha & Total, mean or range \\
\hline $\begin{array}{l}\text { Latitude \& longitude of historical range } \\
\text { (includes } 30 \mathrm{~km} \text { radius around } \\
\text { each locality) }\end{array}$ & $01^{\circ} 28^{\prime}-2^{\circ} 40^{\prime} \mathrm{S}, 33^{\circ} 36^{\prime}-5^{\circ} 14^{\prime} \mathrm{E}$ & $02^{\circ} 26^{\prime}-^{\circ} 37^{\prime} \mathrm{S}, 36^{\circ} 34^{\prime}-7^{\circ} 37^{\prime} \mathrm{E}$ & $03^{\circ} 05^{\prime}-4^{\circ} 02^{\prime} \mathrm{S}, 36^{\circ} 00^{\prime}-6^{\circ} 49^{\prime} \mathrm{E}$ & $01^{\circ} 28^{\prime}-4^{\circ} 02^{\prime} \mathrm{S}, 33^{\circ} 36^{\prime}-7^{\circ} 37^{\prime} \mathrm{E}$ \\
\hline $\begin{array}{l}\text { Historical geographical range } \\
\left(\mathrm{km}^{2} \text {; includes } 30 \mathrm{~km} \text { radius }\right. \\
\text { around each locality) }\end{array}$ & 15,520 & 8,368 & 6,894 & 30,782 \\
\hline $\begin{array}{l}\text { Current geographical range }\left(\mathrm{km}^{2} \text {; }\right. \\
\text { includes } 30 \mathrm{~km} \text { radius around } \\
\text { each locality) }\end{array}$ & 12,260 & 2,793 & 5,687 & 20,740 \\
\hline $\begin{array}{l}\text { Percentage of historical geographical } \\
\text { range currently occupied }\end{array}$ & 79 & 33 & 82 & 67 \\
\hline Altitude (m) & $\begin{array}{l}950-1,580(\text { mean } 1,339 \pm \\
\text { SD } 157, \mathrm{n}=15)\end{array}$ & $\begin{array}{l}800-1,450(\text { mean } 1,258 \pm \\
\text { SD } 203, \mathrm{n}=8)\end{array}$ & $\begin{array}{l}1,300-1,450(\text { mean } 1,365 \pm \\
\text { SD } 59, \mathrm{n}=5)\end{array}$ & $\begin{array}{l}800-1,580(\text { mean } 1,320 \pm \\
\text { SD } 161, \mathrm{n}=28)\end{array}$ \\
\hline Mean annual rainfall $(\mathrm{cm})$ & $\begin{array}{l}55 \text { (SE) to } 105 \text { (NW; Sinclair } \\
\text { et al., 2000) }\end{array}$ & $\begin{array}{l}25-50(\mathrm{~W}) \text { to } 97 \text { (Brown \& } \\
\text { Britton, 1980) }\end{array}$ & 97 (Brown \& Britton, 1980) & $25-105$ \\
\hline Habitat types (White, 1983) & $\begin{array}{l}\text { Somalia-Masai (Acacia- } \\
\text { Commiphora) bushland \& } \\
\text { thickets, \& edaphic grassland on } \\
\text { volcanic soils }\end{array}$ & $\begin{array}{l}\text { Somalia-Masai (Acacia- } \\
\text { Commiphora) bushland \& } \\
\text { thickets }\end{array}$ & $\begin{array}{l}\text { Somalia-Masai (Acacia- } \\
\text { Commiphora) bushland \& } \\
\text { thickets, \& edaphic grassland on } \\
\text { volcanic soils }\end{array}$ & $\begin{array}{l}\text { Somalia-Masai (Acacia- } \\
\text { Commiphora) bushland \& } \\
\text { thickets, \& edaphic grassland on } \\
\text { volcanic soils }\end{array}$ \\
\hline $\begin{array}{l}\text { Minimum number of groups in } \\
\text { current population }\end{array}$ & 8 & 3 & 1 & 12 \\
\hline $\begin{array}{l}\text { Estimated range of number of } \\
\text { individuals in the current } \\
\text { population* }\end{array}$ & $104-592$ & $39-222$ & $13-74$ & $156-888$ \\
\hline
\end{tabular}

${ }^{*}$ Patas group size in Laikipia, Kenya, is 13-74 individuals (Chism \& Rowell, 1988). This range is applied here to estimate the number of patas in each of the three populations. 
R. Radke, pers. comm.). This is the easternmost record for patas in the Serengeti. Grimshaw et al. (1995) mentioned the isolation of the Kilimanjaro population from the Serengeti population, and stated that patas are absent from Amboseli National Park, Kenya. We note, however, that patas were observed near Lake Amboseli until c. 1983 (De Jong et al., 2008).

The gaps between the three populations of patas in central north Tanzania appear to have increased since 1995 (Fig. 1). The distance between the Serengeti population and the Kilimanjaro population was probably $140-200 \mathrm{~km}$ pre1996 but now appears to be $180-240 \mathrm{~km}$. The Serengeti population is separated from the Kilimanjaro and Arusha populations by the Eastern (Gregory) Rift Valley, a wellknown barrier to the distribution of primates in East Africa (Butynski \& de Jong, 2007). Here lie Lake Natron, Lake Manyara, the vast, treeless, short grass plains of the Serengeti Plateau, and the highlands of the Ngorongoro Crater with its montane forest. The distance between the Serengeti population and the Arusha population remains $120-180 \mathrm{~km}$. No evidence was found that the three populations were connected historically but the Kilimanjaro and Arusha populations were probably connected in the not too distant past. There now appears to be a gap of c. 30-90 $\mathrm{km}$ between these two populations. This gap is comprised of Afromontane vegetation, bushland and thicket, and supports a high human population and highly degraded habitats. It is not known if the Kilimanjaro population is, or was, connected to the population in central south Kenya.

Patas in other parts of East Africa are reluctant to drink from rivers (Hall, 1965; Chism \& Rowell, 1988). In many areas in Kenya patas have the option of drinking from cattle troughs, water tanks, or dams (Chism \& Rowell, 1988; Isbell \& Chism, 2007; De Jong, et al., 2008). Water provisioning on cattle ranches in Kenya may be beneficial for the survival of the species in Kenya (Isbell \& Chism, 2007; De Jong et al., 2008). Patas do drink from rivers and streams in Senegal (Dupuy, 1973). We believe that patas in the western Serengeti drink from pools in the Rubana River and, possibly, Grumeti River, as these have historically been the only sources of water available to them during the dry season.

In Kenya patas are closely associated with A. drepanolobium woodland (Isbell, 1998; Isbell \& Young, 2007). Recent encounters with patas in all three populations in Tanzania were also in A. drepanolobium woodland, with the exception of the Sametu Kopjes (Fig. 1, Table 1) where patas were seen in grassland (R. Radke, pers. comm.). In the western Serengeti $A$. drepanolobium occurs south-east of Rubanda Village in the Ikona Open Area and in the Ikorongo Game Reserve but no patas sightings were reported from these areas.

In Tanzania patas occur mainly in semi-arid Acacia woodland. This habitat is threatened by degradation, loss and fragmentation, as well as by loss of species (Emerton \&
Mfunda, 1999; Kabigumila et al., 2005). The Acacia woodlands within the range of the patas populations of Kilimanjaro and Arusha continue to be lost as a result of the activities of the rapidly growing human population. If trends continue, habitat degradation and loss are expected to reduce and isolate Tanzania's three populations of patas further. The minimum number of groups of southern patas at present is 12 , and the number of individuals remaining is probably $150-900$ (Table 2 ).

Patas is categorized as Least Concern on the IUCN Red List (IUCN, 2008) but the southern patas Erythrocebus patas baumstarki has yet to be assessed. Based upon its small, declining, and fragmented distribution $(<20,700$ $\left.\mathrm{km}^{2}\right)$, low number $(<900$ individuals $)$, and decline in geographical range (33\% since 1995), E. p. baumstarki should be categorized as Endangered on the basis of criteria C2ai (IUCN, 2001).

Our study represents a preliminary step towards the conservation of the southern patas. Priority actions for the long-term conservation of this taxon are: (1) Establish a network of interested people throughout the subspecies' range to monitor the size and age/sex composition of the groups of patas they encounter, with the resulting data compiled in PatasBase, a database for patas conservation (De Jong \& Butynski, 2008). (2) Interview members of communities throughout central north Tanzania to assess further the taxon's distribution and abundance and to gain insights into patas habitat and water source use, crop raiding and threats. (3) Conduct a detailed field study of distribution and abundance to assess the taxon's conservation status, determine threats and establish a baseline for monitoring. (4) Undertake a detailed ecological and behavioural study. (5) Prepare a conservation action plan and have this plan implemented by the responsible management authorities in Tanzania.

\section{Acknowledgements}

We thank Brian Harris, Ed Sayer, and Lee Fuller of the Grumeti Community and Wildlife Conservation Fund for their assistance during our visit and for sharing their data on patas in the western Serengeti. The field surveys were supported by a grant from the National Geographic Society to LAI and by Conservation International. We also thank Robert Asher, Daphne Hills, Paula Jenkins, Jean-Pierre Dekker, George Frame, David Erickson, Gerard Ambrose, David Peterson, Chris Parker, Alastair Kilpin, Antonio Sirolli, Hugh Marshall, Peter Mbari, Anthony Kaschula, Dirk Kreulen, George Schaller, Peter Jones, Kim Howell, Neil Stronach, William Newmark, Richard Estes, Alan Rodgers, Tom Struhsaker, Reinhard Radke, Charles Foley, Hans and Ute Klingel, Truman Young, Michelle Hutt, Anabel and Geoff Harries, and James Croft for unpublished information on their observations of patas. We also thank 
two anonymous reviewers for their valuable comments on the manuscript.

\section{References}

Ahn, P.M. \& Geiger, L.C. (1987) Kenya Soil Survey-Soils of Laikipia District. Ministry of Agriculture, National Agricultural Laboratories, Nairobi, Kenya.

Brown, L.H. \& Britton, P.L. (1980) The Breeding Seasons of East African Birds. The East Africa Natural History Society, Nairobi, Kenya.

Butynski, T.M. \& De Jong, Y.A. (2007) Distribution of the potto Perodicticus potto (Primates: Lorisidae) in eastern Africa, with a description of a new subspecies from Mount Kenya. Journal of East African Natural History, 96, 113-147.

Chism, J. \& Rowell, T.E. (1988) The natural history of patas monkeys. In A Primate Radiation: Evolutionary Biology of the African Guenons (eds A. Gauthier-Hion, F. Bourlière, J.-P. Gautier \& J. Kingdon), pp. 412-438. Cambridge University Press, Cambridge, UK.

DE Jong, Y.A. (2004) Distribution and abundance of patas monkeys (Erythrocebus patas) in Kenya, and their use of human infrastructures. MSc. thesis, Oxford Brookes University, Oxford, UK.

De Jong, Y.A. (2006) Monkey in red. Swara, 29, 26-28.

De Jong, Y.A. \& Butynski, T.M. (2008) Eastern Africa Primate Diversity and Conservation Program. Http://www.wildsolutions.nl [accessed 2 November 2008].

De Jong, Y.A., Butynski, T.M. \& Nekaris, K.A.I. (2008) Distribution and conservation of the patas monkey Erythrocebus patas in Kenya. Journal of East African Natural History, 97, 83-102.

Dupuy, A.R. (1973) Premier inventaire des mammifères du Parc National de Basse Casamance (Sénégal). Bulletin de l'Institut fondamental de l'Afrique Noire, 35, 186-197.

Elliot, D.G. (1913) A Review of the Primates. Monograph Series Vol. 3, Anthropoidea. American Museum of Natural History, New York, USA.

Emerton, L. \& Mrunda, I. (1999) Making Wildife Economically Viable for Communities Living Around the Western Serengeti, Tanzania. Unpublished Report. Evaluating Eden Project (IIED) \& the Community Conservation Research Project, Universities of Manchester and Cambridge, UK, and University of Zimbabwe, Harare, Zimbabwe, and the African Wildlife Foundation, Nairobi, Kenya.

Grimshaw, J.M., Codeiro, N.J. \& Foley, C.A.H. (1995) The mammals of Kilimanjaro. Journal of East African Natural History, $84,105-139$.

Groves, C.P. (2001) Primate Taxonomy. Smithsonian Institution Press, Washington, DC, USA.

HALL, K.R.L. (1965) Behavior and ecology of the wild patas monkey (Erythrocebus patas) in Uganda. Journal of Zoology, 148, 15-87.

Hill, W.C.O. (1966) Primates. Comparative Anatomy and Taxonomy, Vol. 6: Catarrhini, Cercopithecoidea, Cercopithecinae. Edinburgh University Press, Edinburgh, UK.

IsBeLL, L.A. (1998) Diet for a small primate: insectivory and gummivory in the (large) patas monkey (Erythrocebus patas pyrrhonotus). American Journal of Primatology, 45, 381-398.

Isbell, L.A. (in press) Patas monkey Erythrocebus patas. In The Mammals of Africa (eds T.M. Butynski, J. Kingdon \& J. Kalina). Elsevier, Amsterdam, Netherlands.

Isbell, L.A. \& Chism, J. (2007) Distribution and abundance of patas monkeys (Erythrocebus patas) in Laikipia, Kenya, 1979-2004. American Journal of Primatology, 69, 1223-1235.

Isbell, L.A. \& Young, T.P. (2007) Interspecific and temporal variation of ant species within Acacia drepanolobium ant domatia, a staple food of patas monkeys (Erythrocebus patas) in Laikipia, Kenya. American Journal of Primatology, 69, 1387-1398.

IUCN (2001) 2001 Categories and Criteria (version 3.1). IUCN, Gland, Switzerland [http://www.iucnredlist.org/static/categories_criteria_ 3_1, accessed 2 November 2008].

IUCN (2008) 2008 IUCN Red List of Threatened Species. Http:// www.iucnredlist.org [accessed 2 November 2008].

Kabigumila, J.D.L., Mvungi, A. \& Nahonyo, C.L. (2005) Environmental Impact Assessment for the Proposed Reintroduction of the Eastern Black Rhinoceros (Diceros bicornis michaeli) in Western Serengeti, Tanzania. Unpublished Report. Department of Zoology and Marine Biology, University of Dar es Salaam, Tanzania.

Kingdon, J. (1971) East African Mammals, An Atlas of Evolutions in Africa. Vol. 1. University of Chicago Press, Chicago, USA.

Kingdon, J. (1997) The Kingdon Field Guide to African Mammals. Academic Press, New York, USA.

Lernould, J. (1988) Classification and geographical distribution of guenons: a review. In A Primate Radiation: Evolutionary Biology of the African Guenons (eds A. Gauthier-Hion, F. Bourlière, J.-P. Gautier \& J. Kingdon), pp. 54-78. Cambridge University Press, Cambridge, UK.

Matschie, P. (1905) Einige anscheidend neue meerkatzen. Sitzungsberichten der Gesellschaft Naturforschender Freunde, 10, 262-275.

Napier, P.H. (1981) Catalogue of Primates in the British Museum (Natural History) and Elsewhere in the British Isles. Part II: Family Cercopithecidae, Subfamily Cercopithecinae. British Museum (Natural History), London, UK.

Sinclair, A.R.E, Mduma, S.A.R. \& Arcese, P. (2000) What determines phenology and synchrony of ungulate breeding in Serengeti? Ecology, 81, 2100-2111.

Swynnerton, G.H. (1945) A revision of the type-localities of mammals occurring in the Tanganyika Territory. Proceedings of the Zoological Society of London, 115, 49-84.

Swynnerton, G.H. (1958) Fauna of the Serengeti National Park. Mammalia, 22, 435-450.

Swynnerton, G.H. \& Hayman, R.W. (1951) A checklist of the land mammals of the Tanganyika Territory and the Zanzibar Protectorate. Journal of the East Africa Natural History Society, 20, 274-392.

Tappen, N.C. (1960) Problems of distribution and adaptation of African monkeys. Current Anthropology, 1, 91-120.

White, F. (1983) The Vegetation of Africa. A Descriptive Memoir to Accompany the UNESCO/AETFAT/UNSO Vegetation Map of Africa. UNESCO, Paris, France.

Williams, J.G. (1987) A Field Guide to the National Parks of East Africa. Collins, London, UK.

Wolfheim, J.H. (1983) Primates of the World: Distribution, Abundance and Conservation. University of Washington Press, Seattle, USA.

\section{Biographical sketches}

Yvonne A. De Jong studies the distribution, taxonomy and conservation status of the primates of eastern Africa. Tномаs M. BUTYNSKI has long been involved with primate research and conservation in tropical Africa, especially in eastern Africa and on Bioko Island, Equatorial Guinea. His current research focuses on questions related to primate distribution, taxonomy and conservation status. Lynne A. Isbell has focused her field research on the behaviour and ecology of primates in East Africa since 1980. Her more recently developed interests include reconstructing relationships between primates and their predators over evolutionary time. CLAIRE LEWIS is based in the western Serengeti, working in wildlife management, conservation and law enforcement. 